Volume 1, Number 2, 2004, pp. 1 24

\title{
Global Flows, Local Hubs, Platforms and Corridors ; Regional and Economic Integration in Northeast Asia
}

\author{
Peter J. Rimmer ${ }^{*}$
}

\begin{abstract}
Toyota's internationally coordinated production system in Asia and its selection of supply bases in South America and South Africa highlights the significance of recognizing global network firms and the global hub-and-spoke logistics system that has been developed to meet their needs. This system underpins the expansion of container shipping, air freight and telecommunications. Recognition of Main Street, linking Europe, Asia and North America with cul-desacs in Africa, Australasia and Central and South America, provides a framework for examining the relative importance of the system's hubs and terminals across different modes and regions. This analysis provides the basis for identifying and ranking key regional logistics platforms in Northeast Asia and their attraction as headquarter sites for global network firms. Examining the logistical situation pertaining after the end of the Cold War in the early 1990s and a decade later is used to gauge progress towards regional economic integration in Northeast Asia.
\end{abstract}

Keywords : Air Freight, Air Passenger, Container Shipping, Global Logistics, Global Network Corporations, Hub-and-Spoke System, Internet, Regional Logistical Platforms and Corridors.

\section{CONTEXTUALIZING LOGISTICS IN NORTHEAST ASIA}

Improving the international logistics system across Northeast Asia, encompassing China, Japan, Hong Kong SAR, the Koreas, Mongolia and Taiwan, provides an opportunity for capitalizing on strengthening economic ties and cross-border production (Fig. 1). Rather than stressing the rivalry and great-power conflicts that persist in surviving Cold War issues - the Korean Peninsula, the Taiwan Straits and assorted islands in the South China Sea - the emphasis is on facilitating regional cooperation in 'the movement, storage and handling of goods and materials across the entire logistics chain from producer to consumer, from point of origin to point of demand' (COA, 2002a: ix). Although efficient and effective logistics are critical to a multinational corporation's competitive position, central governments in Northeast Asia are recognizing the importance of logistics policy in improving their national competitive advantage.

\footnotetext{
- Peter J. Rimmer is Emeritus Professor and Visiting Fellow, Division of Pacific and Asian History, Research School of Pacific and Asian Studies, The Australian National University, Canberra, ACT, Australia and Adjunct Professor of Urban Development and Housing, Centre for Developing Cities, University of Canberra, Canberra, ACT, Australia. e-mail : pjrimmer@actewagl.net.au
} 
These governments are seeking to capitalize on the economy-wide benefits to be derived from a world-class logistics industry: a greater market reach, a wider choice of inputs and products, and less waste within the economy.

Figure 1. Location map of Northeast Asia.

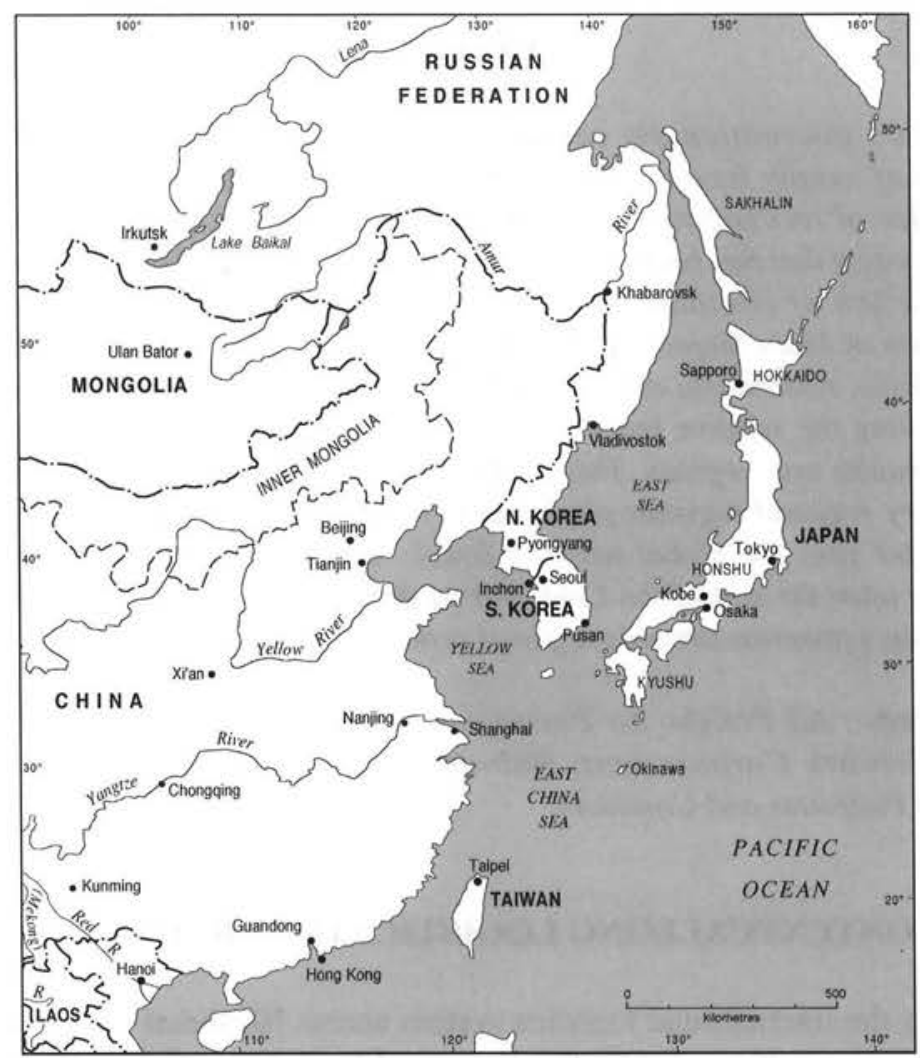

A history of political fragmentation and marked differences in population growth and levels of economic development between individual countries makes improvements to international logistics systems in Northeast Asia difficult when compared with other regions of the world, particularly Western Europe. The history of Asian fragmentation stems from the disruption of the Chinese-centred tribute system by colonialism from the mid-nineteenth century until the Second World War (Rozman, 1999).

After the brief attempt at a unified transport and communications system under Japan's Greater Asian Co-prosperity Sphere there was dislocation during the Cold War when China and the Soviet Union and their collaborators confronted the United States and its allies in Japan, Korea and Taiwan. Whereas United States policy in Europe bolstered cooperation, bilateral relations between Washington and Beijing, 
Seoul and Tokyo have weakened economic integration in Northeast Asia. However, a greater spirit of regional cooperation has been generated by the economic success of Japan offering an alternative capitalist model for Asian development to the United States; China's shift to market socialism; and the relative success at economic integration by the Association of Southeast Asian Nations (ASEAN) (Pempel, 2004).

Unlike Southeast Asia, there is resistance to regional cooperation in Northeast Asia as China, Japan and Korea have been reluctant to surrender sovereignty over transport and communications to any over-arching regional body. A recurrent theme is that the China has little faith in Japan, Japan is doubtful about China, and Korea is diffident about both China and Japan (Pempel, 2004; Rhie, 2002).' Yet China, Japan and Korea are now participating in top-down regional organizations with strong transport and communications components such the Asia Pacific Economic Council (APEC) and make up the three countries in ASEAN plus 3. Significantly, there are also more informal inter-governmental arrangements typified by regular meetings between port administrators in China, Japan and Korea. Since the Plaza Accord of 1985 economic linkages in Northeast Asia have been intensified by private corporations and financial institutions based in Japan, Korea and Taiwan investing in China, which also has attracted investment from Malaysia and Singapore.

Ad hoc groups drawn from governments, corporations, universities and individuals from both inside and outside the region, have also met to focus on improving specific aspects of logistics, typified by the meetings organized by the East-West Center in Hawaii, the Korea Transport Institute and the Northeast Asia Economic Forum (Jun, 2000; Ha et al, 2002a,b). The greater reliance on these informal groups suggest that Northeast Asia may have more in common with logistics developments in South and Central America than the European Union. This observation raises three issues: how does Northeast Asia fit into global logistics patterns; how can the key logistical platforms and corridors in Northeast Asia be identified; and how has the development of logistical developments proceeded since the end of the Cold War in early 1990s? In pursuing these issues there is no strict adherence to any narrow definition of Northeast Asia, such as the northern provinces of China, Japan and the Koreas. This decision reflects, in part, the greater openness of Northeast Asia compared with an element of protection inherent in the definition of the European Union (Fig. 2). Depending on the particular issue, the appropriate geographical scale of analysis canvassed ranges from sub-regional to global.

\footnotetext{
' Won-bok Rhie's (2002) cartoon-style book, Korea Unmasked, provides important insights into the longstanding differences between China, Japan and Korea. In particular, Rhie highlights the important influence exerted by their respective continental, island and peninsula locations on their historical development. Culturally, Rhie likens China to France, Japan to the United Kingdom and Korea to the Balkans. Surely, in any comparisons with Europe from a logistical viewpoint, Korea should be regarded as occupying a position analogous to that of the Benelux countries (Belgium, the Netherlands and Luxembourg).
} 
Figure 2. Estimated gross national product adjusted for purchasing power parity by economy in 2002

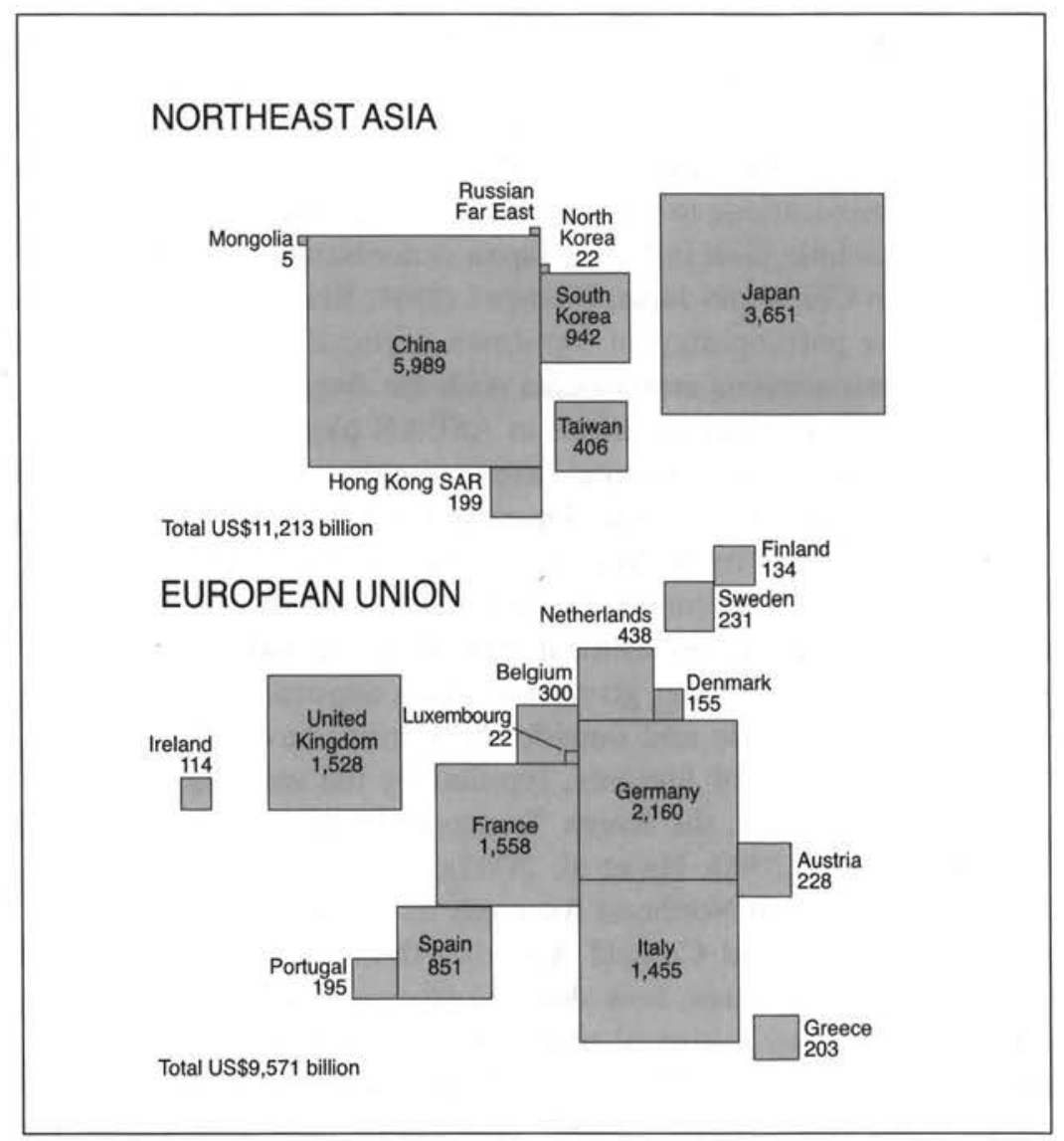

Source : CIA, 2003

Initially, Northeast Asia is put into a global logistics perspective by examining worldwide container, air freight and communications flows and relating them to local (regional) hubs. Elements from this analysis are used to identify key logistics platforms and transport and communications corridors in Northeast Asia. The effects of these developments on regional economic integration are considered by comparing the current situation with that pertaining after the end of the Cold War in the early 1990 s when there was a rash of attempts to create new logistical arenas.

\section{THE GLOBAL HUB-AND-SPOKE SYSTEM}

Global network firms strip the world to its bare essentials when they recognize six continental areas: Africa, Asia, Australasia (Oceania), Central and South America, Europe and North America. This reductionism is reflected in Toyota's internationally 
coordinated production system (Fig. 3). Within Asia, manufacturing bases are pivoted on Thailand as its global manufacturing base, with operations for manufacturing engines and main components located in India, Indonesia, Japan, the Philippines and other Asian centers (Toyota, 2003). This Asian nucleus supplies pick-up trucks and multipurpose vehicles to more than eighty nations or regions. Also it supplies engines and components intra-regionally within Asia, extra-regionally within Australasia, and, more specifically, to both South Africa and Argentina. Further, Toyota has designated South Africa as a supply base for delivering pick-up and multipurpose trucks to both African and European markets. Similarly, Argentina performs the same function for both Central and South American markets. Toyota is expected to increase production and exports from both of these bases suggesting the Southern Hemisphere may yet become an important production base.

Figure 3. Toyota's internationally coordinated production system

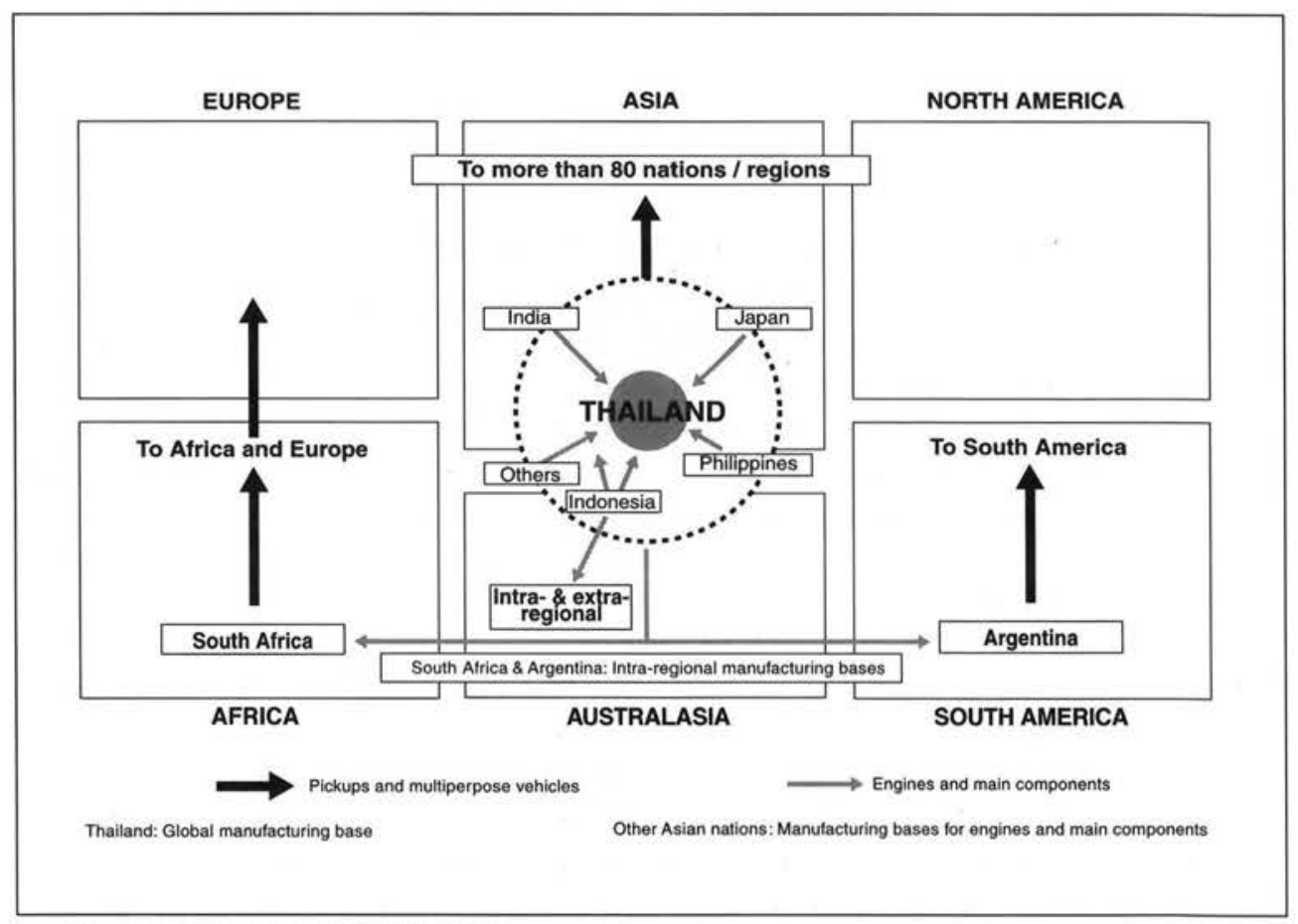

Source : Based on TMC, 2003; 29

The needs of global network firms - spurred by the rapid industrialization of Asia has led to the intensification of inter-continental connections in the Northern Hemisphere between Asia and Europe, and Asia and North America (Fig. 4). Progressively, these connections have been transformed into a prime, east-west, transcontinental axis spanning the world that can conveniently be described as Main Street. Three north-south offshoots from this global-spanning axis link cul-de-sacs: Europe to Africa, Asia to Australasia and North America to Central and South Amierica. 
Figure 4. The global hub-and-spoke system

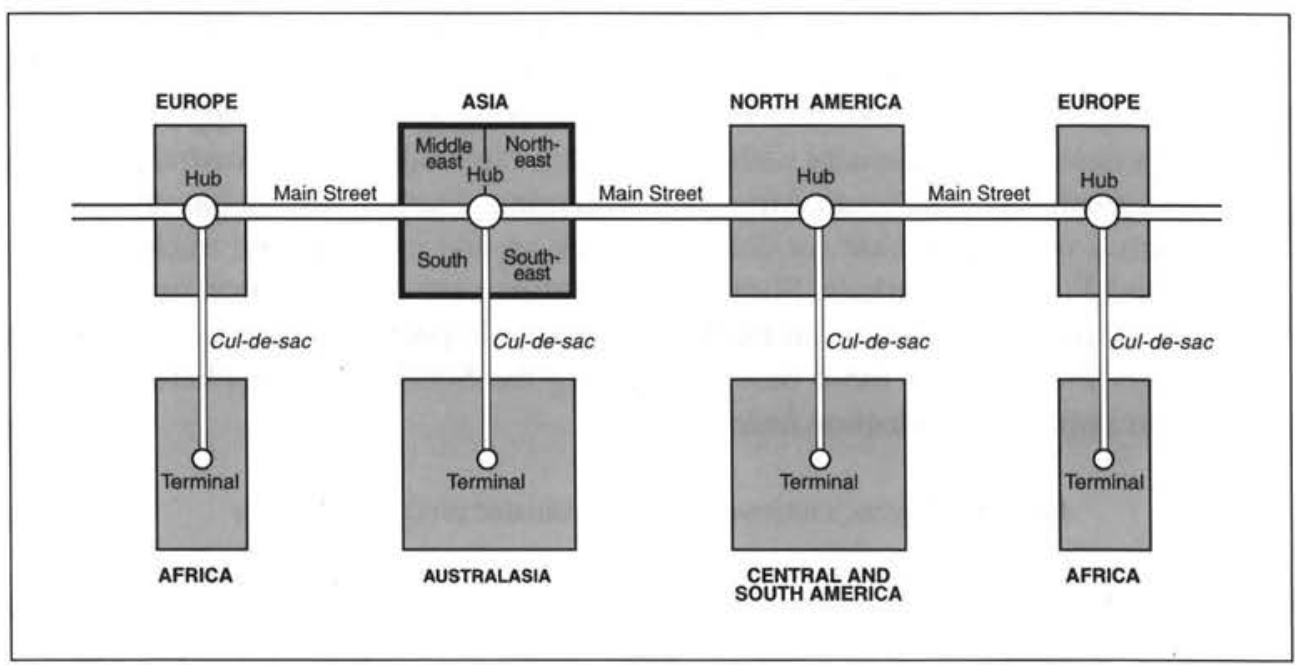

Source : Rimmer, 2002

To what extent is the resultant global hub-and-spoke pattern reflected in flows of shipping containers, air freight and telecommunications? Given the persistence of the network structure comprising Main Street and cul-de-sacs there is the potential for hubs at the intersection between the two. At the end of the cul-de-sacs there is scope only for terminal activities as the opportunity for hubbing is constrained. To what extent have hubs appeared in global container shipping, air transport and telecommunications networks to match this pattern?

\section{Container movements}

An examination of estimated container shipping movements in 2003 measured in Twenty-Foot Equivalent Units (TEUs) highlights the pivotal position of Asia (Fig. 5a). Main Street was the dominant axis, comprising the Trans-Pacific (two-way total 12.2 million TEUs), the Trans-Suez (10.4 million TEUs) and the Trans-Atlantic (6.0 million TEUs) routes. North-south movements involving the cul-de-sacs were much weaker - the strongest link being between Central/South America and North America (3.1. million TEUs) followed by Australasia and Asia, and Africa and Europe. The second and third north-south routes were both smaller than the leading cross-links between Asia and Central/South America. Conversely, those between Europe and Australasia were the smallest recorded. The weakest connections of all were between the three continents in the southern hemisphere emphasizing there was no bypassing of Main Street. Movements within Asian trade (7.4 million TEUs) surpass the TransAtlantic trade and rival the Trans-Suez trade in size. 
Figure 5. World container movements showing world trade routes and the top-25 hubs, 2003

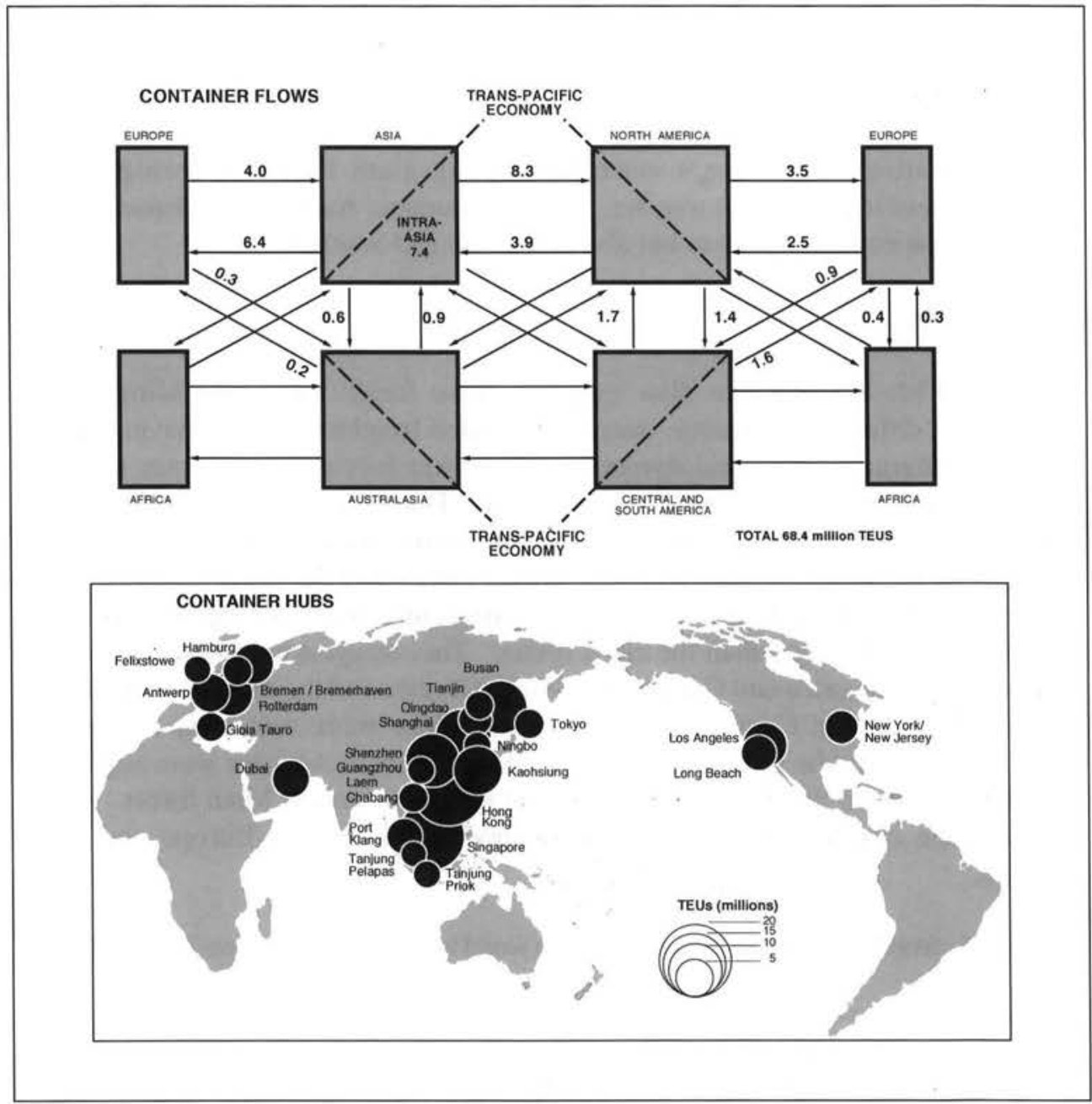

Source : Date from CI, 2003; Boyes, 2004

In 2003 sixteen of the top- 25 container hub ports or load centers were in Asia, compared with six in Europe, three in North America and none in Africa, Australasia and Central and South America (Fig. 5b). Within Asia there is one regional hub in the Middle East (Dubai), ten in Northeast Asia, none in South Asia and five in Southeast Asia. In Northeast Asia Hong Kong has maintained its position as the world's leading container hub (20.1 million TEUs). Six other Chinese load centers, notably Shanghai, Shenzhen (Chiwan, Shekou and Yantian), Qingdao, Tianjin, Guangzhou and Ningbo, are now in the top-25, with Xiamen pressing for inclusion, as China's manufactured exports flow in containers to the rest of the world. Both Shanghai and Shenzhen have pushed the major transshipment ports of Busan and 
Kaohsiung down the rankings and could be vying for the top-two positions, particularly after the completion of Shanghai's Yangshan Island development in 2005. With plans for a new port, Qingdao could also be moving up the world container league (Wang and Slack, 2003). Tokyo is the only surviving Japanese port in the top25 because Kobe, Nagoya and Yokohama have all been omitted as the country's container throughput has been outpaced by China, which has ridden the strong wave of globalization to become a veritable trading giant based on foreign direct investment and technological transfer. China's container trade will continue to grow at the expense not only of Japan but also of Taiwan and Southeast Asia.

\section{Air freight}

In 2000 Main Street was also apparent in air freight. The weightings of the components differ in importance, despite scheduled freighter services having similar logistical characteristics and dynamics of market forces to container shipping operations and the air-passenger system (Fig. 6a). During a good year for air carriers, the leading route was Asia-Europe with 3.1 million tonnes of air freight, closely followed by the Trans-Atlantic with 2.8 million tonnes and the faster growing TransPacific with 2.3 million tonnes. Again the north-south routes linking Main Street to the cul-de-sacs are larger than the cross routes. The strongest north-south route was between North America and Central and South America and the main cross route was between Europe and Central/South America. Once more east-west movements between Africa/Middle East, Australasia and Central/South America were negligible, underlining that the Southern Hemisphere had nothing to match Main Street. Again, Asia had the largest intra-continental movement followed by Europe and North America.

Figure 6. World air freight movements showing world trade routes and the top- 25 hubs, 2000

(a)

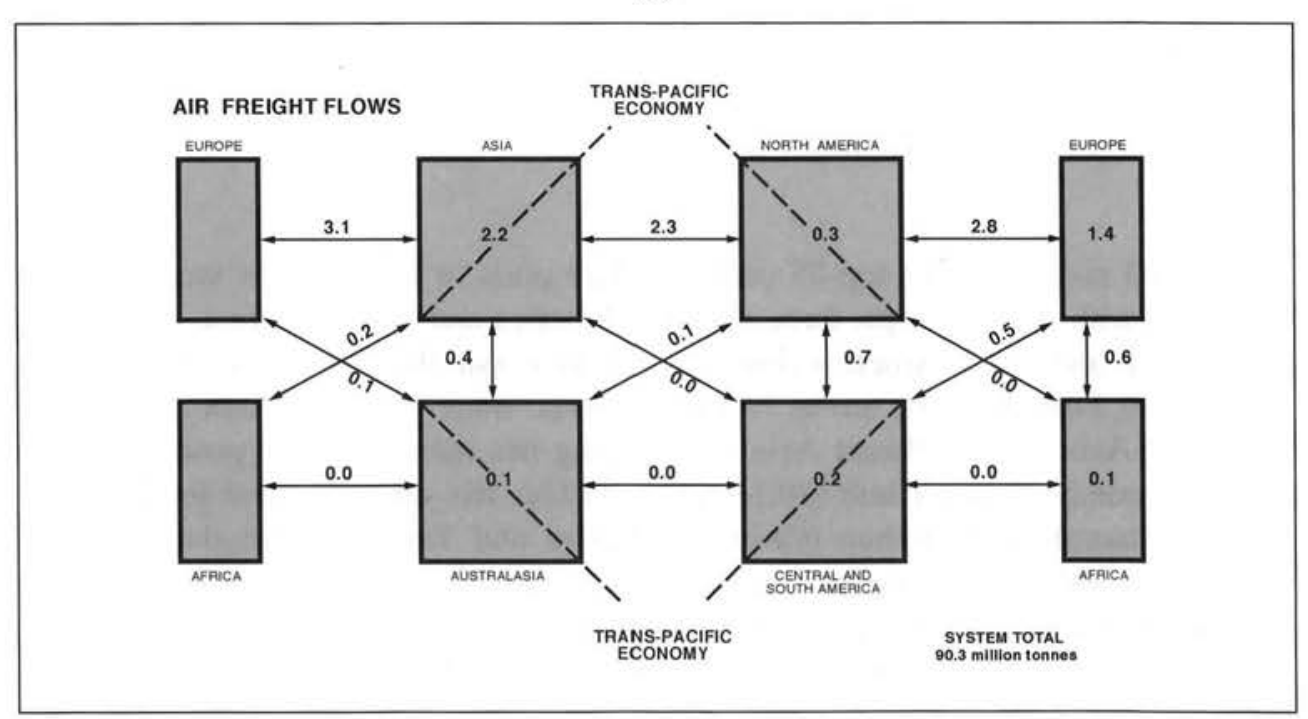


(b)

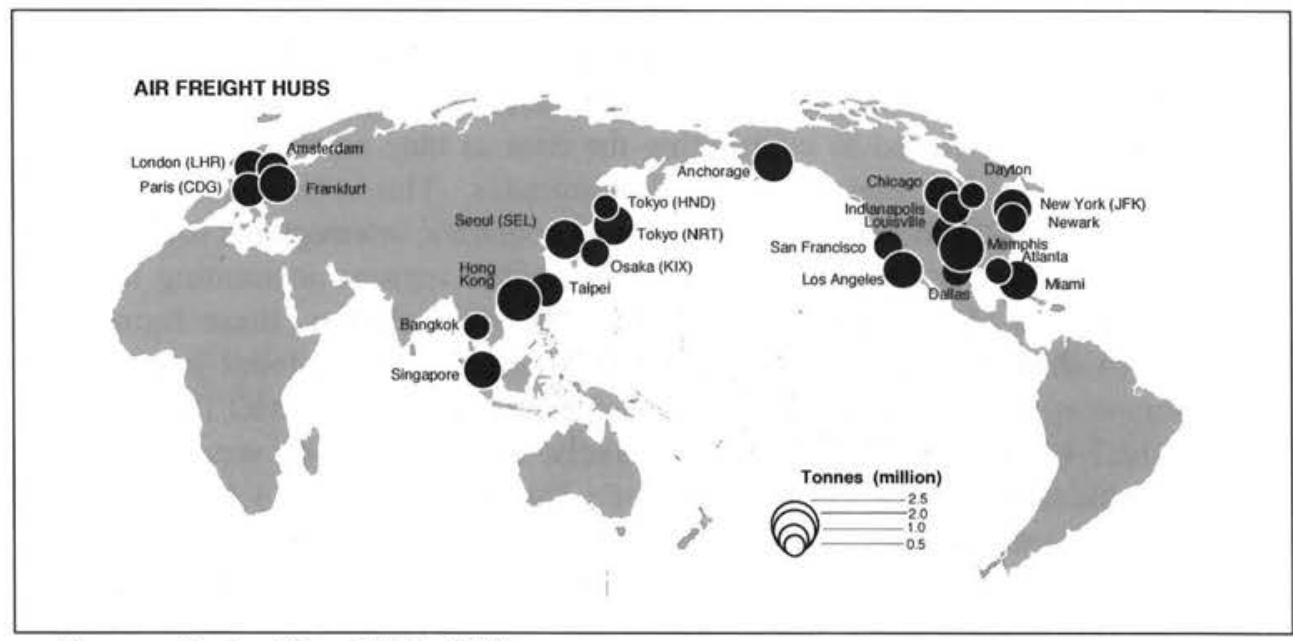

Source : Derived from IATA, 2001

In 2000 eight of the top-25 air freight hubs based on international and domestic freight were in Asia, compared with four in Europe, thirteen in North America and none in Africa, Australasia, or Central and South America (Fig. 6b). This distribution underlines the degree of control exerted by firms with enormous domestic express markets in the United States, notably Fedex (main hub in Memphis and regional hubs in Indianapolis and Newark) and United Parcel Service (main hub in Louisville). Within Asia there are no hubs in the Middle East, six hubs in Northeast Asia, none in South Asia and two in Southeast Asia. In the all-important Northeast Asian market Hong Kong, with Cathay Pacific, Dragonair and DHL as it main carriers, was ranked second in the world after Memphis (though first in international freight) followed by Tokyo (Narita) ranked fourth and Seoul (Gimpo) sixth. Also ranked in the top-25 were Taipei, Osaka (KIX) and Tokyo (Haneda). If the air freight at Tokyo (Narita) and Tokyo (Haneda) were amalgamated into a single figure, Tokyo would be the world's leading generator of cargo. Conversely, none of China's airports were listed in the top-25 air freight rankings, suggesting that there is a marked difference between shipping cheap goods and time-sensitive, high-cost items. This situation is unlikely to persist because several airports in China are likely to rise in the rankings, including Beijing, Shanghai (Pudong), Guangzhou (Baiyun) and Shanghai (Hongqiao). Indeed, the aggregate for both Shanghai airports was already sufficient for the combined unit to rank in the top-25. These developments presage that Northeast Asia (including intra-Asian movements) will lead the world in air freight stemming from: the rise of e-commerce; the increase in knowledge-intensive goods with higher value to weight ratios comprising a greater share of global trade (e.g. computers and electronics); a long-term downward trend in air freight rates; and the adoption of supply chain management practices, with a premium on speed and reliability (Bowen, 2004). 


\section{Telecommunications}

In 2000 Main Street was evident in international traffic in telecommunications measured in billions of Minutes of Telecommunications Traffic (MiTT) (Fig. 7a). Care needs to be exercised in interpreting the data as they cover only 52.4 billion minutes from the global total of 132.7 billion minutes. This is because the data are restricted to the top-20 routes for the 130 largest countries; interregional routes below 100 million minutes are excluded; and traffic within regions accounting for 62.9 billion minutes is also omitted (TGI, 2002: 93). Nevertheless, these figures are sufficient to show the importance of North America at the 'global junction' of telecommunications flows between the Trans-Atlantic (14.6 billion MiTT) and TransPacific (12.7 billion MiTT) flows. Conversely, there is a much weaker flow of telecommunications traffic on Main Street's Europe-Asia link (4.4 MiTT). The strongest and most unbalanced connection of all is the north-south link within the Western Hemisphere (14.9 billion MiTT). The only other significant north-south connection is between Europe and Africa. There was no comparable figure for Asia and Australasia because the two areas were merged in the statistics. Traffic on the cross-links between North America and Africa and Europe and Central and South America was small. Underlining these differences are marked differences in interregional international bandwidth.

Figure 7. World telecommunications movements showing world trade routes and the top- 25 hubs, 2000

(a)

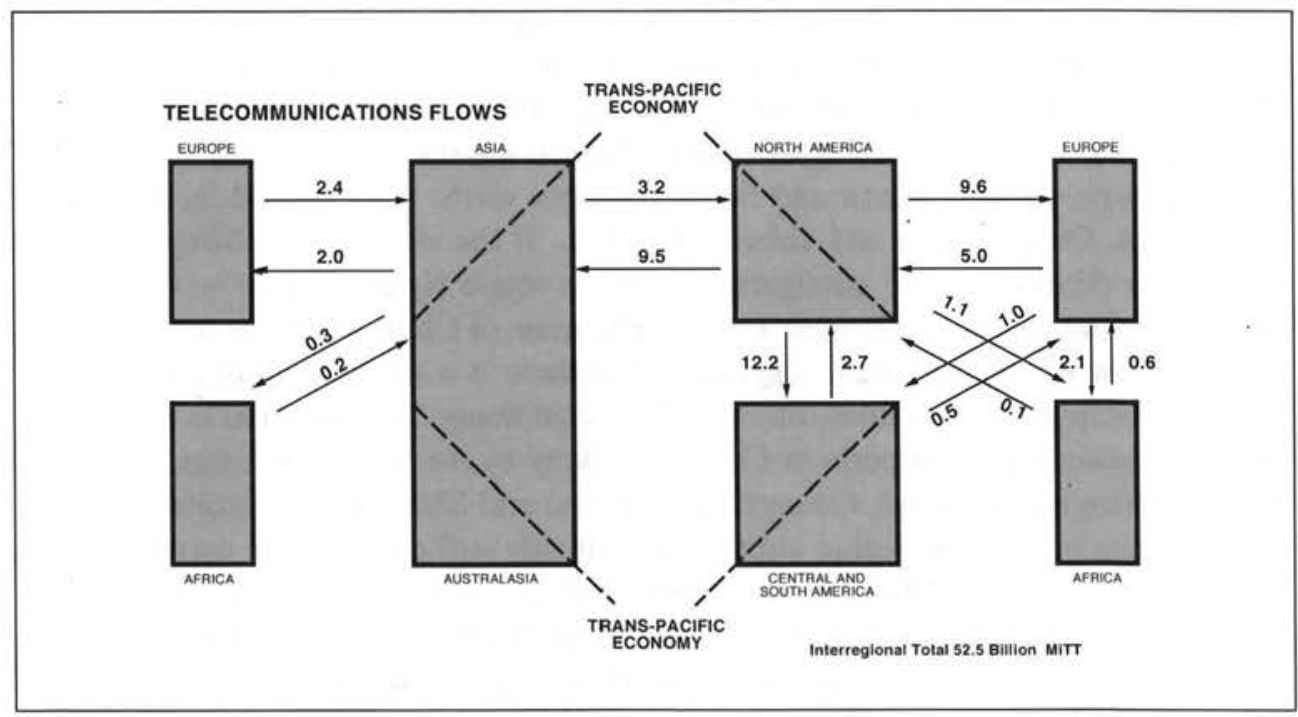


(b)

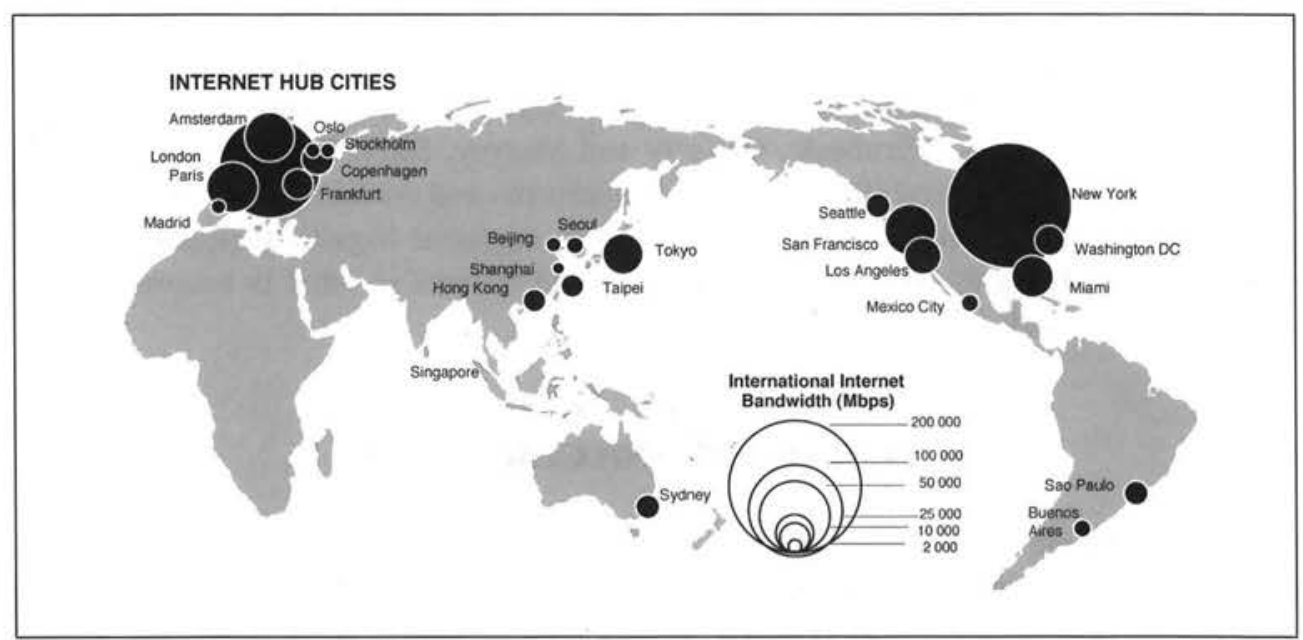

Source : Data from TGI, 2002

In 2002 seven of the top-25 interregional Internet hub cities ranked in Megabits (Million bits per second or Mbps) were located in Asia, compared with eight in Europe, seven in North America, none in Africa, one in Australasia and two in Central and South America (Fig. 7b). Within Asia there are no hubs in the Middle East, six in Northeast Asia, none in South Asia and one in Southeast Asia (TGI, 2003; cf. AN, 2003). In Northeast Asia Tokyo (19,300 Mbps) ranked ninth in Internet bandwidth connected across international borders from Consolidated Metropolitan Statistical Areas or equivalents (domestic and intra-regional routes are omitted). This figure was small compared with the first and second-ranked hubs of New York (179,278 Mbps) and London (115,615 Mbps) where advanced telecommunications infrastructure is used for e-commerce, online retailing and e-government. Yet Tokyo dwarfed fifteenth-ranking Hong Kong (5,764 Mbps), Taipei, Seoul, Beijing and Shanghai. This pattern may reflect the dominance Tokyo exerts over flows of complex digital information in Asia, including audio and video. Tokyo's position in telecommunications has been reinforced by the emergence of a common Asian pop culture in which Japanese corporations export karaoke and J-pop to ensure that the cultural experiences of the middle class in Hong Kong, Seoul, Tokyo and Taipei are becoming virtually identical, despite increasing diversity with the wider distribution of K-pop and Korean movies.

Differences between the three modes are not entirely unexpected because the driving forces vary between container shipping, air freight and telecommunications. Container shipping responds to the scarcity of resources; air freight activity to the inclusion of speed in globally dispersed production activities; and telecommunications to marked cultural differences. However, all three modes are underpinned by the hub-and-spoke system. As hub-and-spoke topologies allow for economies of scale by consolidating flows from a set of geographically dispersed services onto trunk connections with the hub city, the system is the most 
economically viable arrangement for private interests and preferred to meshed topologies. Any disruptions in shipping, air and telecommunication service from a massive node failure have the potential to be economically (and socially) catastrophic for global network corporations and city-regions, and may have a significant spillover effect on 'spoke cities' (Grubesic, O'Kelly and Murray, 2003; Rahman and Findlay, 2003). This latent vulnerability in logistical platforms and corridors and their inherent survivability and reliability is compounded in regional logistical platforms and corridors, involving the prospect of multiple node failures in what is becoming 'the network of networks'.

\section{PLATFORMS AND CORRIDORS}

The challenge of defining regional logistical platforms and corridors led to the development of the multilayered hub concept that integrates sea-land, air and telecommunications networks (Fig. 8). In this representation A, B and C are single platforms with different levels for handling goods, air freight (and passengers) and information flows. The links between the platforms are the corridors accommodating movements of goods, people and information.

Figure 8. The multilayered network

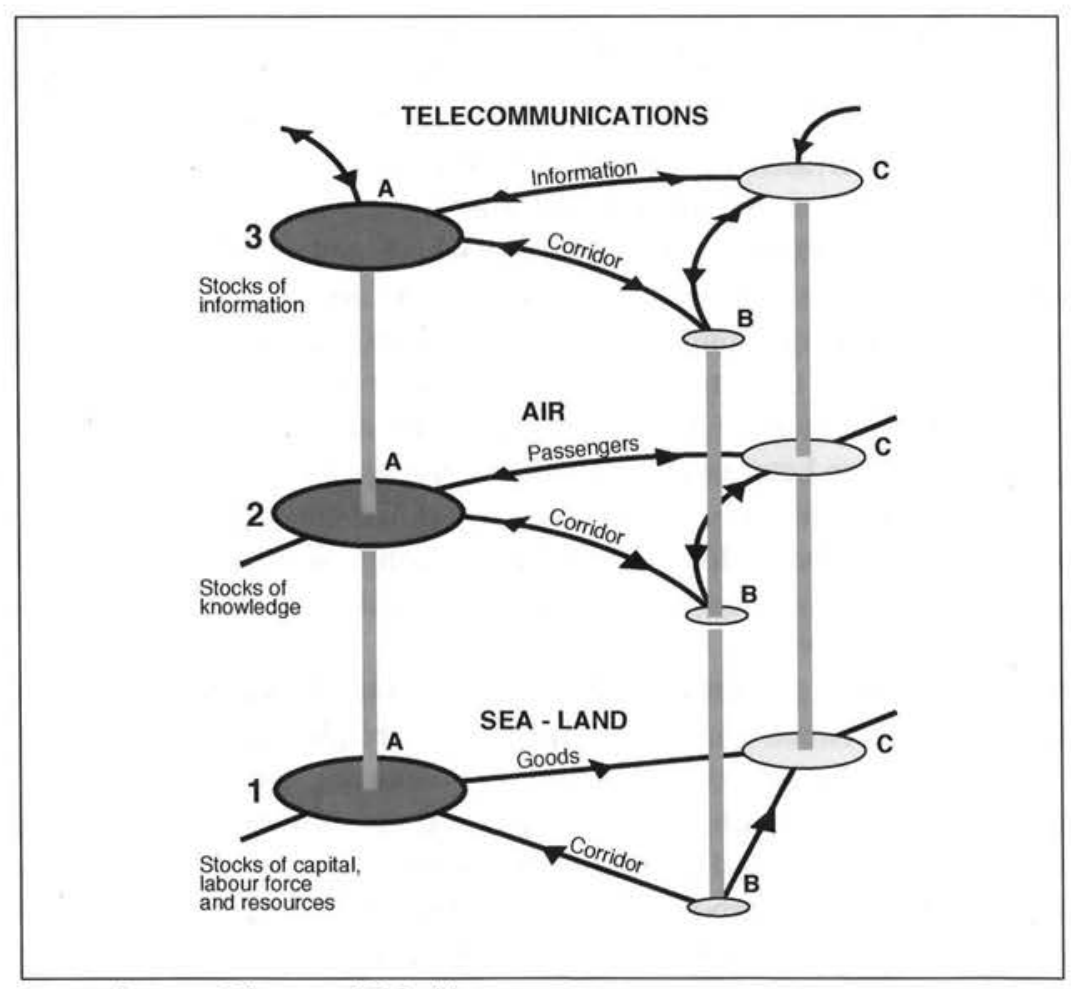

Source : Rimmer, 1999: 44 


\section{Platforms}

As the rankings of Internet hub cities airports and container ports reflect the premium which global network firms place on nodality they provide a useful guide to the relative strength of individual platforms (Table 1). Where platforms have multiple airports and container ports they are grouped together even, where in the case of Hong Kong, they include entities outside their administrative boundaries.

Table 1. World Top-50 Ranking of Internet, Air Passenger, Air Cargo and Container Shipping Ports, 2002

\begin{tabular}{|c|c|c|c|c|c|}
\hline \multicolumn{2}{|c|}{ Internet } & \multicolumn{2}{|c|}{ Air freight } & \multicolumn{2}{|c|}{ Container shipping } \\
\hline Hub city & $\#$ & Airport & \# & & \# \\
\hline \multicolumn{6}{|l|}{ Platforms } \\
\hline \multirow[t]{2}{*}{ Tokyo } & 7 & Tokyo (NRT) & 4 & Tokyo & 19 \\
\hline & & Tokyo (HND) & 23 & Yokohama & 25 \\
\hline \multirow[t]{3}{*}{ Hong Kong } & 15 & Hong Kong & 2 & Hong Kong & 1 \\
\hline & & Guangzhou & 29 & Guangzhou & 27 \\
\hline & & & & Shenzhen & 6 \\
\hline Taipei & 16 & Taipei & 13 & Keelung & 30 \\
\hline Beijing & 20 & Beijing & 25 & Tianjin & 24 \\
\hline \multirow[t]{2}{*}{ Shanghai } & 25 & Shanghai (PUG) & 27 & Shanghai & 4 \\
\hline & & Shanghai (SHA) & 36 & Ningbo & 31 \\
\hline \multicolumn{6}{|c|}{ Proto-platforms } \\
\hline Seoul & 19 & $\begin{array}{l}\text { Seoul (ICN) } \\
\text { (Seoul Gimpo }\end{array}$ & $\begin{array}{r}6 \\
63)\end{array}$ & (Incheon & 74) \\
\hline Nagoya & 48 & & & Nagoya & 29 \\
\hline \multirow[t]{2}{*}{ Osaka } & 49 & Osaka & 20 & Kobe & 28 \\
\hline & & & & Osaka & 42 \\
\hline \multicolumn{6}{|l|}{ Other nodes } \\
\hline & & & & Busan & 3 \\
\hline & & & & Kaoshiung & 5 \\
\hline & & & & Qingdao & 15 \\
\hline & & & & Xiamen & 34 \\
\hline & & & & Dalian & 49 \\
\hline
\end{tabular}

Note : Top-25 rankings are in bold type.

Source : TGI. 2003; Allett, 2003; ACI, 2003; ACW, 2003; JOC, 2001.

Using this procedure it is possible to identify regional distribution platforms and proto-platforms in Northeast Asia from the wider array of nodes in the Asia-Pacific region (Fig. 9).

- Platforms are those represented in the top-25 rankings of Internet hubs, freight airports and container ports;

- Proto-platforms are those represented in at least two of the top-25 rankings; and

- Other nodes are represented only once in the rankings. 
The platforms/proto-platforms offer regional bases for the global network firms to manage their global economic operations because they are the 'spaces' through which flow commodities, air freight and passengers and information, including capital. They are also the 'spaces' of capital accumulation on a world scale. As commanding components of the global economic system, the regional platforms reflect the economic power they command (i.e. the gross regional domestic product).

Figure 9. Platforms, proto-platforms and other nodes in the Asia-Pacific

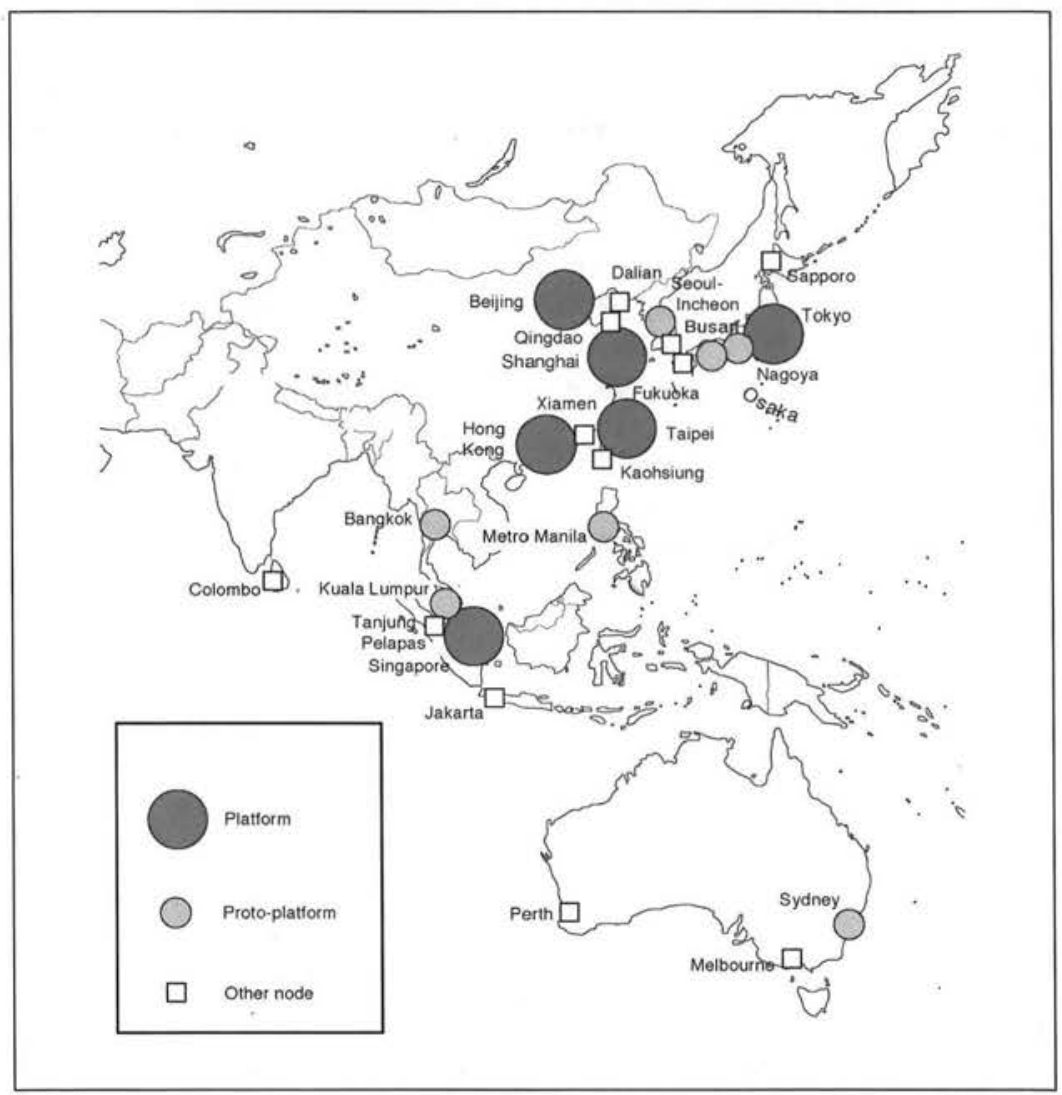

Source : Based on Rimmer, 1997: 450

Five fully-fledged platforms are recognized in Northeast Asia: Tokyo-Yokohama (Keihin), Hong Kong-Guangzhou-Shenzen (Pearl River Delta), Taipei-Keelung (Northern Taiwan), Beijing-Tianjin (Bohai) and Shanghai-Ningbo (Lower Yangtze). As the Port of Incheon does not rank among the top-25 container ports, SeoulIncheon is defined as a proto-platform together with Nagoya and Osaka-Kobe (Hanshin), which both lack a strong Internet base. Busan and nine other nodes in Northeast Asia are regarded as classic port cities.

The development effort being expended on Pentaport, particularly on the seaport, 
may enhance Seoul-Incheon's status from proto-platform to a fully-fledged regional platform. While the platform hosts the headquarters of a leading air freight company and those of two of the world's largest container shipping companies, there is no world-ranking telecommunications company.

In 2000 Seoul-Incheon ranked fifth among East Asia's leading platforms/proto platforms in gross regional domestic product adjusted for purchasing power parity (Table 2). On this score Seoul-Incheon was positioned behind Tokyo-Yokohama, Osaka-Kobe, Shanghai and Nagoya-Shizuoka but ahead of Beijing-Tianjin and Hong Kong. Adding the business port and the leisure port to Pentaport's modern transport and communications infrastructure promises to enhance Seoul-Incheon's relative standing in Northeast Asia, offering a well-trained labor force and an attractive quality of life, even if the addition of Gyeonggi province does not give a regional market that matches the size of its rivals.

Table 2. Purchasing Power Parity (PPP) Gross Income for Selected Cities, Platforms and Regions, 2000(US\$ billion Purchasing Power Parity)

\begin{tabular}{l|r|l|c|l|r|}
\hline City & $\begin{array}{c}\text { SUS } \\
\text { bn }\end{array}$ & $\begin{array}{l}\text { Platform/ } \\
\text { proto-platform }\end{array}$ & $\begin{array}{c}\text { \$US } \\
\text { bn }\end{array}$ & Region & $\begin{array}{c}\text { \$US } \\
\text { bn }\end{array}$ \\
\hline \hline Tokyo & 581 & Tokyo-Yokohama & 783 & Kanto & 1237 \\
\hline Shanghai & 237 & Shanghai & 237 & Lower Yangtze & 975 \\
\hline Hong Kong & 174 & Hong Kong & 174 & Hong Kong-Guangdong & 714 \\
\hline Nagoya & 227 & Nagoya-Shizuoka & 330 & Chubu & 653 \\
\hline Osaka & 274 & Osaka-Kobe & 422 & Kansai & 512 \\
\hline Beijing & 124 & Beijing-Tianjin & 208 & Beijing-Tianjin-Hebei & 470 \\
\hline Seoul & $\mathbf{1 7 8}$ & Seoul-Incheon & $\mathbf{2 1 4}$ & Seoul-Incheon-Gyeonggi & $\mathbf{3 9 0}$ \\
\hline Singapore & 100 & & & & \\
\hline
\end{tabular}

Source : KNSO, 2002; NBSC, 2002; SB, 2002; WB, 2003.

Underlining the importance of platforms, Tokyo's economy is 2.8 times larger than Australia. The significance of this figure is lost because frequent adherence to discussing the world in terms of nation states. Singapore is treated as being on a par with Japan though its economy is but a fraction of Tokyo's economy.

These results, stemming from the ranking of platforms based on transport and communications and the size of their economies, have similarities, to the positioning of Northeast Asian centers in the roster of world cities produced by the Globalization and World Cities Group at Loughborough University (Fig. 10). All platforms and proto-platforms in Northeast Asia were ranked as 'world cities', except for Nagoya. Tokyo and Hong Kong were classed as alpha world cities on a par with eight other metropolises including Singapore; Seoul was recognized as a beta city together with nine others including Sydney; and Beijing, Osaka, Shanghai were classed as gamma world cities with thirty-one other centers. The comparison suggests that the concept of world city-regions rather than world cities per se may give a better guide to logistical strength. 
Figure 10. The Globalization and World Cities (GaWC) inventory of world cities

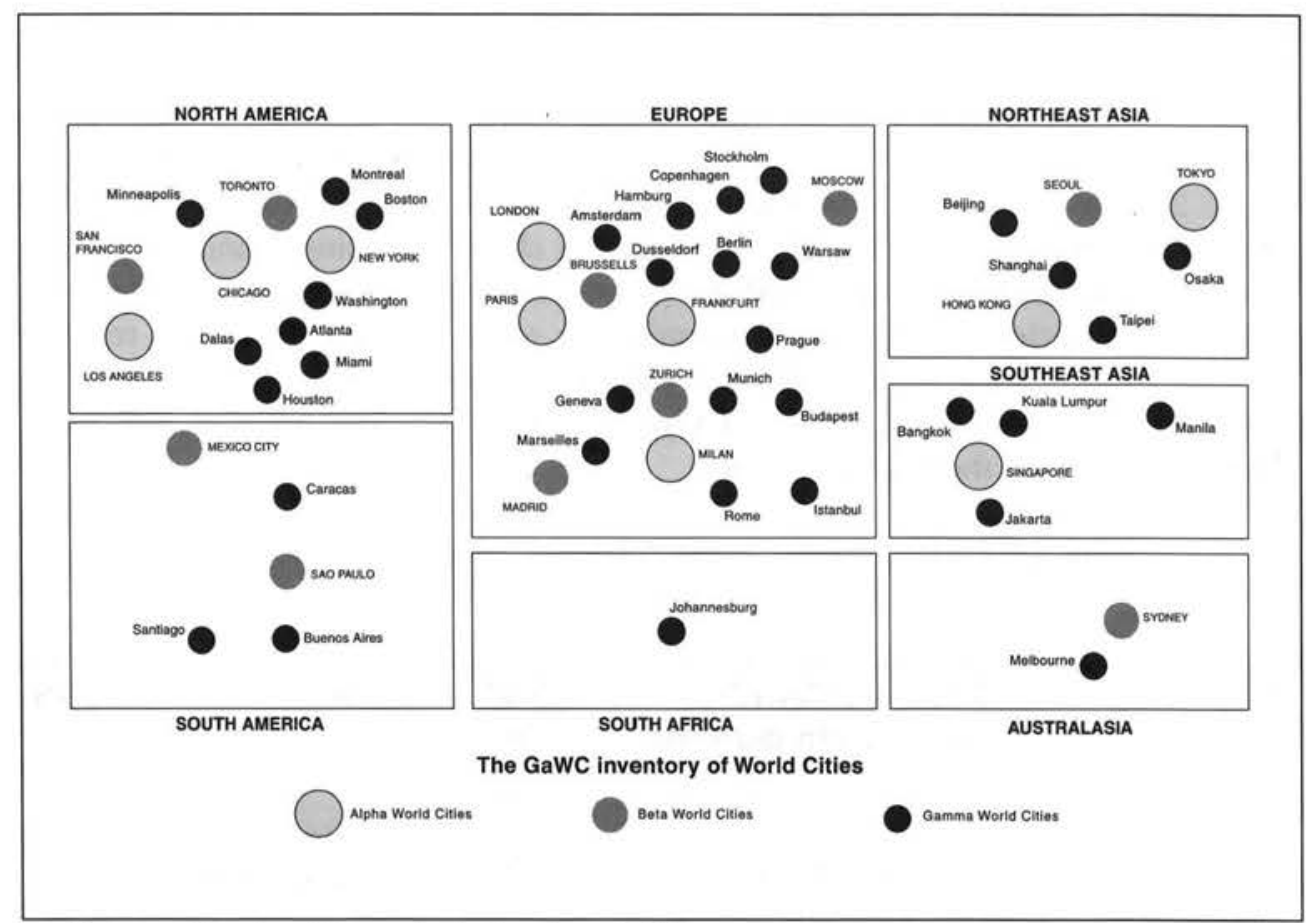

Source : Based on Beaverstock, Smith and,1999

\section{Corridors}

The comprehensive national territorial plans of the core economies of China, Japan and Korea have made varying degrees of reference to how major logistical platforms can be linked into the Northeast Asia region (Rimmer, 2003). Korea's Fourth Comprehensive National Territorial Plan, 2000-2020, for instance, envisages major interconnections with the Pan-Yellow Sea, the Eurasian Continent, the Russian Far East, the Pan-East Sea Rim and central and south China and Southeast Asia. Within the Koreas, the main South Coastal, West Coastal and East Coastal Axes are identified (Figure 11 inset). A more detailed plan includes a Central Spine and Southern, Mid-Central and Northern Axes linking urban centers on the west and east coasts to provide a lattice pattern. 
Figure 11. Corridors planned for Korea, 2002-2022

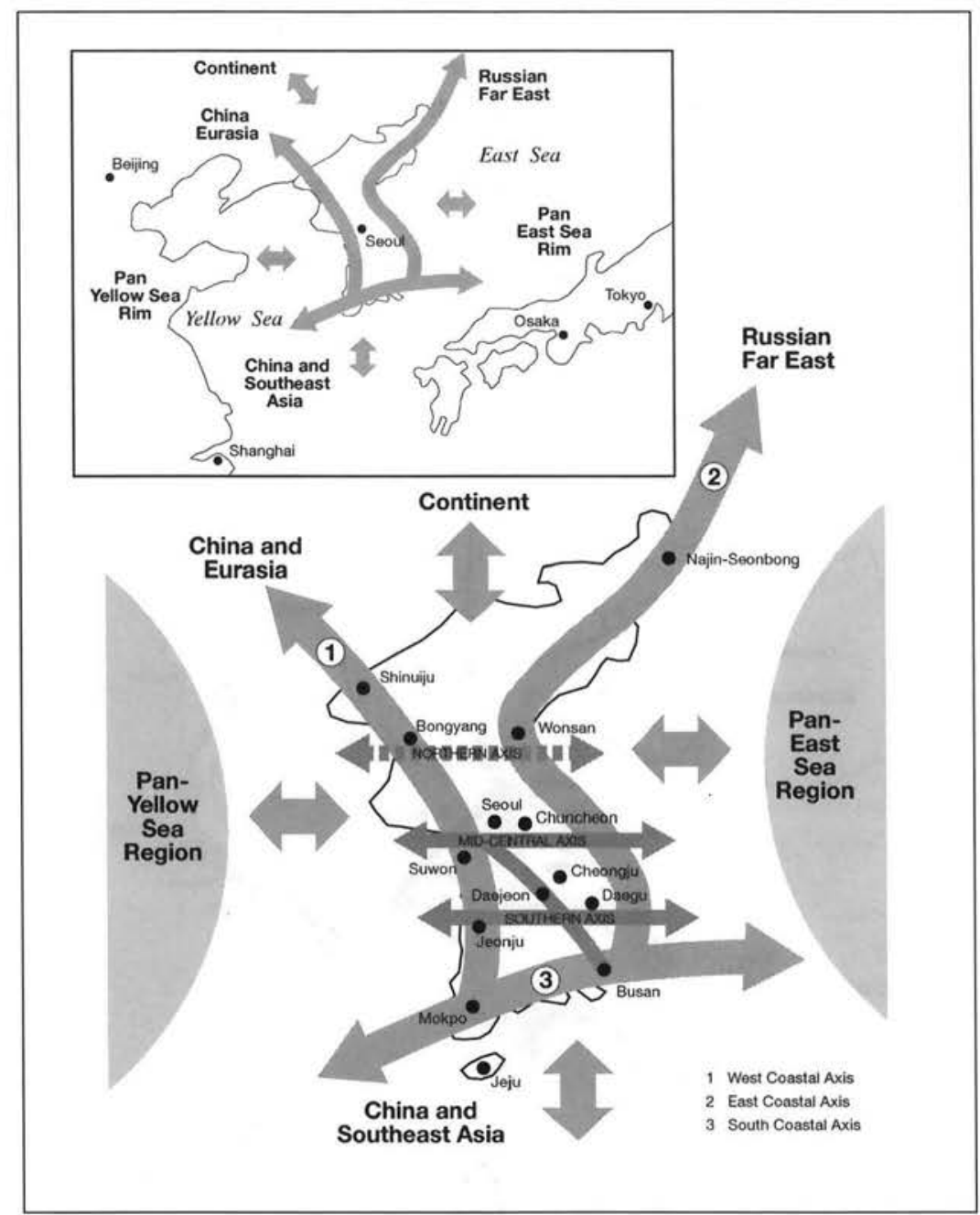

Source : ROK, 2002

Similar national territorial plans have been developed in both China and Japan. At best, like the Korean plan, these are preoccupied with domestic circumstances and local territorial responses. They only hint at how Northeast Asia could be integrated through homogenizing and universalising pressures exerted by being integrated through logistical platforms into the global market (Rimmer, 2002). A step further is proposed here to fill the gap in cross-border linkages by extending the rudiments of China's plan to Japan and Korea (Fig. 12). Future logistical platforms are marked Chinese-style as red areas and the connecting major land corridors as red routes. Recognizing secondary city-regions as yellow areas and secondary corridors as yellow areas fills out the network. Potential corridors connecting Mongolia and the 
Russian Federation, including Korea's main East Coastal Axis, are identified by the author as 'purple routes' to complete the overall spatial structure. The prospects for accelerated hinterland development in this land-locked area based on Chinese and North Korean labor, Russian resources and Japanese and South Korean capital and know-how survive but, apart from natural gas, their prospects have dimmed since early 1990s (Rimmer and Jun, 2000). This raised the issue as to the extent of progress of developing logistical arenas in Northeast Asia over the past decade.

Figure 12. Northeast Asia's major logistical platforms and corridors

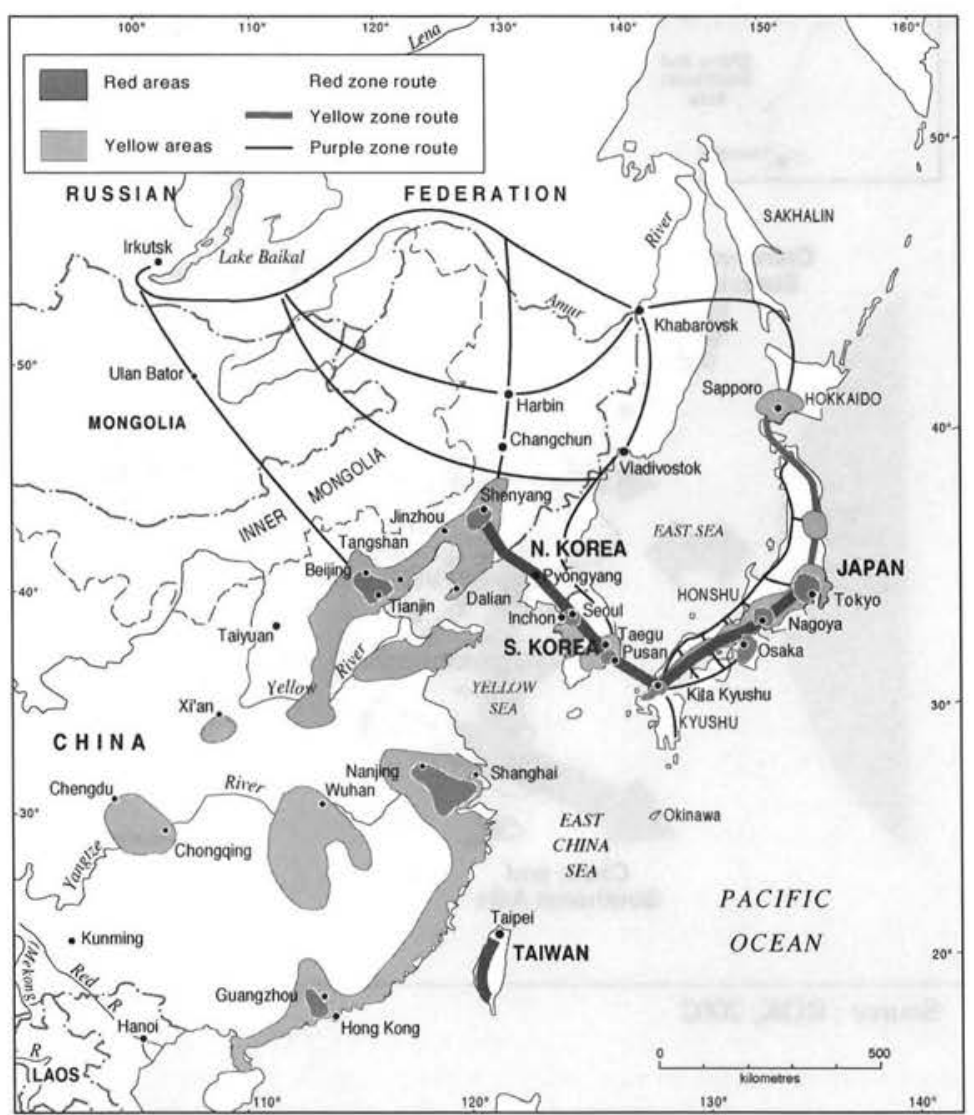

Source : Rimmer, 2003

\section{ECONOMIC INTEGRATION SINCE THE EARLY 1990S}

After the end of the Cold War in the early 1990s there was much enthusiasm for creating a new logistics arena in Northeast Asia as part of the broader regional economic integration of the Asia-Pacific region (Rimmer, 1994). Northeast Asia included three major economic zones - North Asia, the New Golden Triangle and the Indochina Economic Zones - that, in turn, incorporated nested sub-zones. North Asia 
featured both the East Sea sub-zone with Tumen River and the Pan-Yellow Sea subzone including both the Shandong and Liaoning Peninsulas. The New Golden Triangle was pivoted on Hong Kong, Shanghai and Taipei, subsuming the Yangtze, Cross Strait and Pearl River Delta sub-regions, and was expected to become the new manufacturing core of the world economy in the new millennium The Indochina Economic Zone covered the Singapore-Johor-Riau (Sijori) Triangle and a host of extensive copycat schemes in Southeast Asia that lacked the required political will and necessary transport and communications connections to be successful. Also recognized was the prospect of an East Asian Corridor stretching from Sapporo via Busan to Hong Kong and, more hypothetically, a possible merger with the Southeast Asian Corridor stretching from Bangkok to Singapore to form a Pacific Asia Corridor.

Figure 13. Location of sub-regions in Northeast Asia, c. 1993

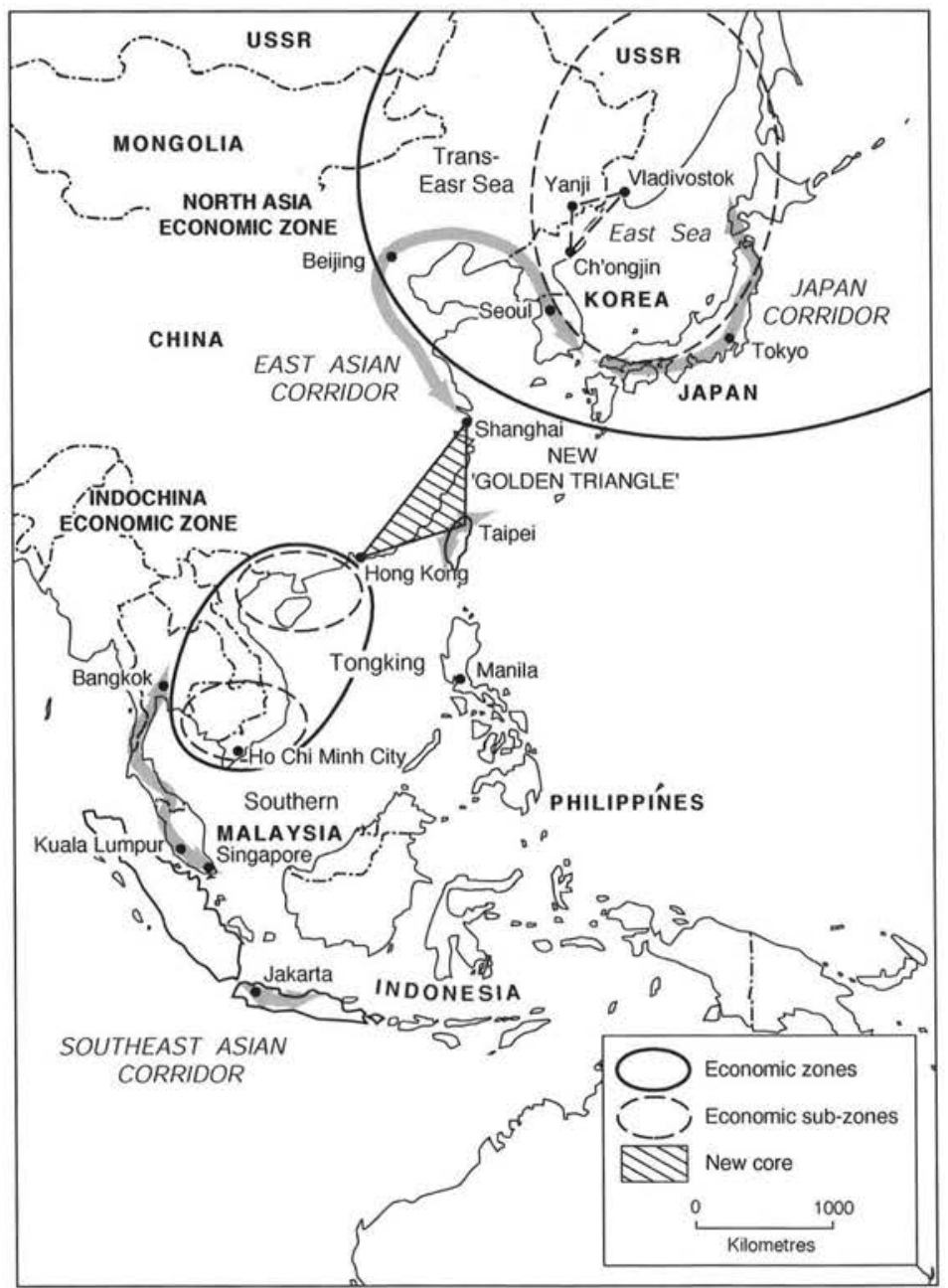

Source : Based on Rimmer, 1994 
Ten years later the Tumen River project has lost momentum, despite marked development on the Chinese side of the border, and is now ranked below the struggling area-wide logistical arenas in Southeast Asia. Although detailed plans have been made for a series of corridors connecting China, Japan and the Koreas with Mongolia and the Russian Far East, most attention will be focused on the major logistical platforms and their interconnecting corridors, particularly as the East Asian 'Super' Corridor is still a feasible proposition. The Golden Triangle concept still has validity. Hong Kong has consolidated its position as a world city of producer services and, arguably, the Pearl River Delta has become the world's leading manufacturing centre and the two areas have become increasingly integrated into a single platform. Shanghai is fast regaining its past glamour as the Yangtze River Delta has developed rapidly as a logistic platform and, as anticipated, Taipei, without unfettered transport and communications access to the mainland, has not kept pace with its rivals. An emerging area of promise is the Bohai-Yellow Sea Corridor where Beijing-Tianjin and a host of port cities, including Qingdao, are undergoing rapid urban industrial transformation as foreign investment and exports have led to manufacturing becoming the leading sector. More specifically, the South Korean Triangle encompassing Seoul, Incheon and Gaesung, is seen as a key logistical center once the railway line connecting the two Koreas is reconstructed. Progress towards the realization of its potential as a hub for Northeast Asia will be monitored closely over the next decade. 
Figure 14. Location of sub-regions in Northeast Asia, c.2003

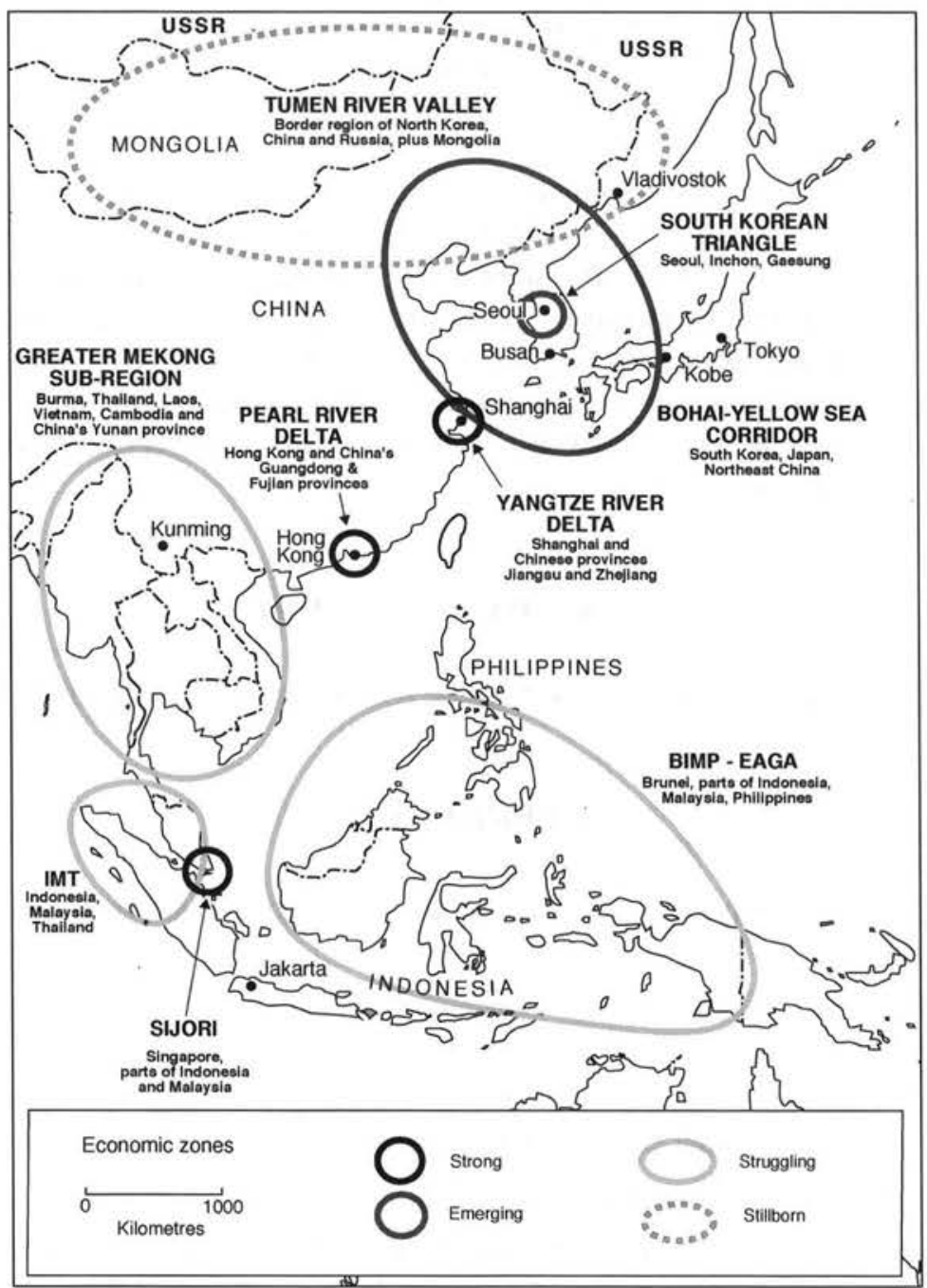

Source : Based on Forochar, 2003

\section{Conclusions}

This study has sought to provide a broad context for discussing logistics developments in Northeast Asia. Global flows, local hubs, platforms, corridors and regional economic integration prospects has been considered to counter the widespread preoccupation with the aggregate mass of national economies. Identifying Main Street, cul-de-sacs and hubs in global container, air freight and telecommunications flows and distilling them into platforms and corridors has enabled us to represent a 'skeleton of the 'substantive economy' of production, trade 
and consumption or, at least, that part of economic activity encompassed by the market economy' (Dick, 1993: 5). In the process we have come to understand the pivotal importance of competing logistical platforms and corridors as the basis for promoting regional integration. The incorporation of logistical platforms into the global economy offers the prospect of tapping growth by attracting foreign funds and expertise.

The task ahead involves comprehending the nature of circulation in its broadest sense within and between the key logistics platforms identified in this study as the basis of managing localization. Inevitably, this strategy focuses attention on the need to revamp institutional frameworks governing logistical platforms. An important corollary is that any policy-making to accelerate the pace of development within logistical platforms should not be confined to transport and communications systems but should embrace all urban networks to draw higher-valued service industries and personnel from abroad.

\section{ACKNOWLEDGEMENTS}

Ian Heyward drew the figures and Dr. Sue Rimmer provided editorial comments.

\section{REFERENCES}

ACI (2003). Top 50 airports by Total Passengers. Airport Council International (pers comm.)

ACW (2003). 'Top 50 cargo airlines', Air Cargo World http://www.aircargoworld.com/features/0903 1.htm

AN (2003). 'Rating the world's top 20 Telecom Hubs', America's Network, 104(13): 40-49. http://web1.epnet.com/citation.asp?tb=1 $\ldots$

Allett, T. (2003) 'Top 100 Airports', Airport International, September: 56-59.

Beaverstock, J.G., Smith, R.G. and Taylor, P.J. (1999), A Roster of World Cities,

GaWC Research Bulletin 5, Loughborough, Globalization and World Cities Study Group and Network, published in Cities, 16 (6), (1999), 445-458.

http://www.lboro.ac.uk/gawc/

Bowen, J.T., (2004). 'The geography of freighter aircraft operations in the Pacific

Basin, Journal of Transport Geography, 12(1): 1-11.

Boyes, J.R.C., (2004). 'Chinese crackers', Containerisation International, March: 85.

CI (2003). Containerisation International Yearbook 2003, London, Informa Ltd.

CIA (2004) The World Fact Book - Field Listing GDP - per capita http://www.cia.gov/cia/publications/factbook/fields/2004.htm

COA (2002). Freight Logistics in Australia: An Agenda for Action, Canberra, Commonwealth of Australia. 
Dick, H.W. (1993), 'East Java in a regional perspective', in H.W. Dick, J. Fox, and J. Mackie, (eds), Balanced Development: East Java and the New Order, Oxford, Oxford University Press: 1-21.

Foroohar, R. (2003). 'Making hubs and spokes', in Boom Towns, Newsweek: Special Edition, October-December: 32-36.

Grubesic, T.H., O’Kelly, M.E. and Murray, A.T. (2003). 'A geographic perspective on commercial Internet survivability’, Telematics and Informatics, 20(1): 51-69.

Ha Hun-Koo, Lee Sungwon and Ye Choongyeol, eds (2003). Comprehensive Study on Building a Regional Distribution and Logistics Hub, Seoul, The Korea Transport Institute and East-West Center

Ha Hun-Koo and Lim Jae-Kyung, eds (2002). Building an Integrated Transport Market for Korea, China and Japan; Elimination of Barriers, Seoul, The Korea Transport Institute and East-West Center

IATA, (2001). World Air Transport Statistics, $45^{\text {th }}$ edition, Montreal, International Air Transport Association.

JOC, (2003). 'World's Top 50 container ports 2002 v 2001', Journal of Commerce, Jul y14-20, 2003. http://www.oocl.com/trade news/20030715.htm

KNSO (2002). Korea Statistical Yearbook, 2002, Seoul, Korea National Statistical Office,

NBSC (2002). China Statistical Yearbook 2000, Beijing, National Bureau of Statistics of China.

Pempel, T.J. (2004). East Asian regionalism [outline of presentation at the symposium on the 'Korean Peninsula, Taiwan: Recent Developments and Prospects, held as the Institute of Oriental Culture, University of Tokyo, 29, Match 2004]. http://glocom.org/opinions/essays/20040405_pempel_east/index.html

ROK (2002). Jae-4-cha Kuk to Jong-hab Gae-wheok, 2000-2020 [The Fourth Comprehensive National Territorial Plan, 2000-2020], Seoul, Dae Han Min Kuk Jung Pan [Republic of Korea].

Rahman S. and Findlay, C. (2003). 'The impact of terrorism on cycle times in international supply chains', Journal of International Trade and Logistics, 1(1): 41-53.

Rhie Won-bok (2002). Korea Unmasked: In Search of the Country, the Society and the People, trans. Jung Un and Louis Choi, Seoul, Gimm-Young Publishers Inc.

Rimmer, P.J. (1994). 'Regional integration in Pacific Asia', Environment and Planning A, 26: 1731-1759.

Rimmer, P.J. (1997). 'Trans-Pacific oceanic economy revisited', Tidjschrift voor Economische en Sociale Geografie, 88(5): 439-456.

Rimmer, P.J. (1999). 'The Asia-Pacific Rim's transport and telecommunications systems: spatial structure and corporate control since the mid-1980s', GeoJournal, 48 (1): 43-65. 
Rimmer, P.J. (2002). 'Global transport: Australia as a cul-de-sac', in C. Shiel (ed.), Australia and Globalisation, Sydney, Evatt Foundation, Sydney, Evatt Foundation

Rimmer, P.J., (2003). 'The spatial restructuring of Northeast Asia in the new millennium', Korea Observer, 34(3): 559-588.

Rimmer, P.J. and Jun Il-soo (2000). 'A vision for an integrated transportation system in Northeast Asia', in Il-soo Jun (ed.), Creating a Regional Transportation System. Seoul, The Korea Transport Institute and East-West Center: 363-405.

Rozman, G. (1999). 'The role of Northeast Asian cities in a global urban network', The Korean Journal of Regional Science, 15(2): 5-19.

SB (2002). Japan Statistical Yearbook 2003, Tokyo, Statistics Bureau/Statistical Research and Training Institute.

TGI (2002). TeleGeography 2002: Global Telecommunications Traffic Statistics and Commentary, Washington DC, TeleGeography Inc.

TGI (2002). TeleGeography 2003: Global Telecommunications Traffic Statistics and Commentary, Washington DC, TeleGeography Inc.

TMC (2003). Annual Report Year Ended March 31, 2003, Tokyo, Toyota Motor Corporation.

WB (2002). World Development Indicators 2002, Washington, D.C., The World Bank. http;//www.worldbank.org/data/wdi2002/globallinks.htm

Wang Jixian J. and Slack, B. (2003). Qingdao fenxi [Qingado port analysis] in Qingdao Shi cheng shi fa zhan lue yan jiu zhuan ti bao gao [Report on developing Qingdao city], unpublished paper. 